\title{
Editorial
}

\section{Are we Listening?}

\section{Meredith Wallace Kazer, PhD, APRN-BC, FAAN \\ Editor-in-Chief}

I had lunch with my mom the day after Dr. Christine Blasey Ford testified before the Senate about her experience of sexual abuse by Supreme Court Nominee Brett Kavanaugh. As we opened our biodegradable Whole Food lunch boxes, my mom said, "I can’t believe she came forward after so many years, without telling anyone. Why now?"

I was stunned for a minute, not expecting this perspective. When I found my voice, I reminded her that I was sexually abused 42 years ago and we never told anyone.

That silenced her.

After a few minutes she shared that when I sustained the abuse by a neighbor who babysat for me, she'd called my pediatrician for advice on how to handle it. She'd suggested they call the police. He'd told her to let it go. "'Boys will be boys,' he'd said. Even your father...," mom continued.

I held up my hand then, still not ready to talk about what happened to me when I was eleven years old.

The National Sexual Violence Resource Center reports that one in every three women and one in six men has experienced some type of sexual violence in their lifetime (https://www.nsvrc.org/statistics). In a university dining hall full of 900 faculty, staff and students, up to 300 have been sexually violated. There are sexual abuse victims in every class, on every team, in the commuter lounge, the offices, the residence halls and the library. Within our academic communities, many faculty, staff and students are holding up their hands, still not ready to talk about it, and grappling with the everyday impacts that sexual violence has on our lives.

Much can be done to impact the epidemic of sexual violence that pervades our college campuses. Education regarding safe and respectful sexual behavior and role modeling kindness and respect for all is inherent in the work we do. Newer Title IX laws have also been implemented to ensure effective communication, swift action and appropriate procedures when sexual misconduct occurs.

But what of those among us who come to school each day with the trauma of sexual violence laid deep in our souls? Are our college and universities willing, able and prepared to listen and care for us? Will we lead off with, "why didn't you tell anyone?" Or will we open our ears and hearts to the shame, hurt, fear humiliation and anger that sexual violence imposes on its victims? Will we create safe spaces, open dialogue and welcoming communities, that say loudly and clearly, come talk to me, you will not be shamed, you will not be judged, we will listen and help you heal?

Thanks to the courage of Dr. Christine Blasey Ford who told her painful story of sexual violence to millions of Americans, we can no longer hide the epidemic of sexual assault in this nation and in our academic communities. The time is now, to proactively open the dialogue on sexual abuse across our campuses, so all victims can find their voice and feel our learned compassion. As a fellow academic, Dr. Ford has opened the door for us. As leaders in academic communities, it is essential that we seize this opportunity to open the door wider and institutionalize the healing process for so many of our faculty, staff and students who have experienced sexual violence. 